\title{
Effects of Seasonal Variations and Location on the Proximate Compositions of Vended Street Food in Parts of Port Harcourt, Rivers State
}

\author{
Oyet Gogomary Israel", Achinewhu Simeon Chituru, Kiin-Kabari David Barine, \\ Akusu Monday Ohwesiri
}

Department of Food Science and Technology, Rivers State University, Port Harcourt, Nigeria

Email address:

gogomaryo@yahoo.com (O. G. Israel)

*Corresponding author

To cite this article:

Oyet Gogomary Israel, Achinewhu Simeon Chituru, Kiin-Kabari David Barine, Akusu Monday Ohwesiri. Effects of Seasonal Variations and Location on the Proximate Compositions of Vended Street Food in Parts of Port Harcourt, Rivers State. World Journal of Food Science and Technology. Vol. 4, No. 2, 2020, pp. 53-61. doi: 10.11648/j.wjfst.20200402.16

Received: March 25, 2020; Accepted: April 13, 2020; Published: April 30, 2020

\begin{abstract}
This study examined the interaction effect of seasonal variations and locations on the proximate compositions of vended street food in parts of Port Harcourt metropolis. The study was carried out using complete randomized block design in factorial experiment. Three (3) Factorials were used (with factor A as Season, B as Location and C as Street Vended foods). The experiment was conducted in dry and raining seasons along the 3 locations (Makoba-station 1, Elekahia-station 2 and Rivers State University-station 3). The Six Food products investigated were roasted plantain, fish, yam, suya, meat pie and doughnuts that were purchased from parts of Port Harcourt city respectively. The foods were sampled twice each seasons and the mean results recorded. The Result for proximate composition of street vended foods during the raining and dry seasons, with moisture content ranged from RF1-3 Wet (58.90 - 62.53\%) and Dry RF1-3 (52.55 - 59.56\%), with the highest moisture content occurring in Fish at Makoba - 62.53\% during the wet season, while the lowest moisture content was recorded by DN1-3 Wet (24.84 - 31.98\%), Dry (19.08-23.52\%) and showed that the Moisture content of each of the food types were significantly different $(\mathrm{P}<0.05)$ with respect to seasons and location. Ash, fat, protein, crude fibre and carbohydrate content of the street vended foods ranged from $0.65-3.32 \%, 0.68-14.43 \%, 1.03-47.35 \%, 1.25-6.45 \%$ and $0.04-$ $51.25 \%$, respectively. Suya samples from Makobar (SY1) gave high crude fibre of $6.45 \%$. High carbohydrate of $51.25 \%, 49.55 \%$ and $47.19 \%$ were showed in samples DN1, DN2 and DN3, respectively and were significantly different $(\mathrm{P}<0.05)$ with respect to location except suya with values of $5.50 \%, 3.26 \%$ and $3.82 \%$ which were not significantly different $(\mathrm{P}>0.05)$ in spite of location. Three-way factorial analysis showed that the interaction effect of seasonal variation and location on the proximate composition of selected street vended foods were significantly different $(\mathrm{P}<0.05)$ and may be due to the processing and food handling methods, species, seasonal effects on the raw materials and not particularly about the location of food samples.
\end{abstract}

Keywords: Seasonal Variations, Proximate Analysis, Street Vended Foods, Protein, Moisture Content

\section{Introduction}

The Long term malnutrition problems of the poor nations will, therefore, not be solved by food aid or food trade with the affluent countries, but rather will depend upon dramatic improvements in their indigenous food production capacity and just as importantly, improvement in the income opportunities of the poor [1]. In response to this analysis, Port Harcourt food industries have witness the emergence of various road side trading and hawking of ready- to -eat foods to close the gap created by income disparity.

Street-vended foods are defined as those foods prepared on the street and ready to eat, or prepared at home and consumed on the street without further preparation [2]. Street foods are especially useful for the very poor, who lack time and facilities to cook, but office workers and other segments of society rely on them. Street foods are adopted because they are inexpensive, the taste is acceptable and they are nutritious meals [3]. Street food vendors usually take their products to their customers and therefore operate from such 
places as schools, office centers, market places, railway stations and motor parks, industrial sites and other street corners where they are ready and numerous clienteles [4].

According to Francis and Mogens [5], Protein malnutrition is considered an important cause of the high death rates among children in low- income countries such as Nigeria. Also, there is proof that protein shortages in infants and very young children can result in retardation in the development (perhaps irreversible) of the brain and nervous system. There are indications that the protein levels may reduce mental alertness and physical efficiency. There is increasing evidence that protein and other nutritional deficiencies results in greatly decreased resistance to infectious diseases, and conversely, that sick children have increased need of protein requirements.

The emergency of street vended food in the local community is a stop gap for the malnutrional imbalance observed by Francis and Mogens, hence the Patronage of street vended food (SVF) is a common practice in a fishing port called Ajegunle in Andoni Local Government Area of Rivers State, occupied predominantly by the Ilaje's of Ondo State. Street Vended foods such as Roasted and dried fish, Plantain (bole eating with fish), beans, moi moi, akara, white rice, fish stew are usually served to children going to school in the morning by parents who were busy with fish processing activities. Also, observed that adults patronized the street vended foods, especially fried fish and roasted pork meat, akara used in combination with the seeping of Ilaje's garri. This open up more of such business opportunities for non Ilaje's in Ajegunle fishing port and across the towns in Andoni, city of Port Harcourt, and many other cities across Nigeria.

It is a common knowledge that street vended food such as roasted plantain, yam, potatoes, fish (Bole) as it is popularly called in Port Harcourt, others are, roasted and boiled corn, bread, kpukpuff, ground nuts, fruits and vegetables such as carrots, cucumber, apple, peeled oranges and sliced pawpaw, water melon and pineapple are major contributors to the nutritional requirements of an average Nigerian. These ready to-eat -food have become a major source of food supplies to workers in small and big establishment alike. The consumers of these foods are not so much concerned about the nutritional composition, hygienic condition and level of microbiological, physical and chemical contamination. It is used as snacks, lunch and dinner to the consumers. The population that patronize these vended foods are diverse, ranging from the poor to middle and upper class and across the various occupation. This huge patronage therefore call for a lucid attention to the health of the population and attendant risk to various opportunistic diseases arising from contamination and infections. We have seen the emergence of these street vended food vendors with mini stalls and canopies hoisted for their customers in some parts of Port Harcourt metropolis, Rivers State and we are concerned with the nutritional values as stop gap for the nutrients requirements of the individual.

Food is one of the prime necessities of life as water and air. The nutrient content available to man is most significant for the daily growth of man. Its limitation in the essential nutrients has been known to cause malnutrition of various degrees. The nutrients derived in these ready-to-eat street vended foods are of importance and determines the quality of the food [6]. According to Ihekoronye and Ngoddy [1], Food is very essential to man's survival, and therefore great attention should be paid to food production, distribution wholesomeness and preservation. Today, it is a known fact that access to quality food is driven by ability to pay. Most people are struggling to meet the food requirements of the family, hence have resorted to quick and cheaper foods vended along the street, as a supplement, without recourse to good hygienic practices. Most workers, such as drivers, mechanics, cleaners, operators, teachers, students and some middle level employees, especially those working in urban business center such as the Universities, and some other areas in Rivers State have good patronage of street vended foods. Also, some highly paid workers, have also found patronage of vended street food, without recourse to food safety and nutrient content. This is also true of workers around oil and gas installations such as terminals and depots, truck marshalling yard, gas plants facilities along the Makoba areas and Industry road in Port Harcourt [7].

According to Brian and Allan [8], "the basic function of Food is to keep us alive and healthy. To be alive is a function of the nutrient composition of the food, which are in two folds, nutrients are to provide materials for growth and repair of tissues, that is to provide and maintain the basic structure of our bodies and to supply the body with the energy required to perform external activities as well as carrying on its own internal activities."

Proximate composition is the term usually used in the field of feed/food and means the six (6) components of moisture, crude protein, ether extract, crude fiber, crude ash and nitrogen free extracts, which were expressed as the content (\%) in the feed, respectively [9]. The measured values of these 6 components in feed are important factors to understand the nature and the properties of the subject food. Proximate composition and it's substances in respective composition are moisture which involved water and volatile substances, crude protein: Pure protein, amino acids and non-protein compounds. Dry matter or Organic matter it include: Crude fat: (Ether extract) Fat, complex lipid, sterols, fatty acids, fat soluble dyes. Crude fiber: Cellulose, hemicellulose, lignin, Nitrogen free extracts: Soluble carbohydrate, hemicellulose, lignin, etc.

The aim of this study is to: examined and assessed the effect of seasonal variations and location on the proximate compositions of street vended foods around oil and gas installations, residential and university environment in Port Harcourt metropolis.

\section{Materials and Methods}

\subsection{Study Area}

Port Harcourt is the capital and largest city in River State, located between the latitudes of $4^{\circ} 46^{\prime} 38.71^{\prime \prime} \mathrm{N}$ and longitudes $7^{\circ} 00^{\prime} 48.24^{\prime \prime} \mathrm{E}$ in the heart of Niger Delta. The Study was conducted in selected parts of Port Harcourt metropolis, 
Rivers States along the following sampling locations: Makoba: Terminal and Deports (Housing Oil and Gas, Truck Park/slump environment) Rivers State University gate (UrbanAcademic Environment) Elekahia (urban- defining Industrial and Residential Area).

\subsection{Methods}

\subsubsection{Experimental Design}

Six food samples each were purchased from the 3 (three) locations in Port Harcourt metropolis for two different days respectively and were wrapped with an aluminum foil paper, transported in an iced cooler to Food Chemistry Laboratory in the Department of Food Science and Technology, Rivers State University, Port Harcourt, Nigeria same day for analysis. The whole study was done using complete randomized design in a factorial experiment. Three factorials were used (Factors A, B and C); factor A represented Season, B Location and C Street Vended food samples given as $2 \times 3 \times 3$ factorials. The vended foods are as shown in Table 1.

\subsubsection{Sample Collection}

A total of 18 (Eighteen) food samples consisting of roasted fish, roasted plantain, roasted yam, Meat Pie, Suya and Doughnut were purchased from roadside food vendors and hawkers along the Rivers State University Gate, Makobar-Industrial settlement, Elekahia-Urban dwellers, all in Port Harcourt city, Rivers State, Nigeria.

Three (3) samples were collected along the three (3) different locations for two (2) day during each season. They were wrapped in an aluminum foil, placed in a cooler and taken to the laboratory from which sub-samples were obtained for the determination of Proximate Compositions. The choice of the samples were carefully made to reflect the most consumed street vended foods in Port-Harcourt. The samples were stored at $4^{\circ} \mathrm{C}$ prior to analysis.

Table 1. Experimental Design: Season, Locations and Food Samples.

\begin{tabular}{llll}
\hline SEASON & STATION 1 & STATION 2 & STATION 3 \\
\hline Raining & RP1 & RP2 & RP3 \\
$\&$ & RF1 & RF2 & RF3 \\
Dry & RY1 & RY2 & RY3 \\
& SY1 & SY2 & SY3 \\
& MP1 & MP2 & MP3 \\
& DN1 & DN2 & DN3 \\
\hline
\end{tabular}

Legends:

RP1=Roasted plantain from Makobar, Port Harcourt.

RP2=Roasted plantain from Elekahia, Port Harcourt.

RP3 $=$ Roasted plantain from Rivers State University, Port Harcourt.

RF1=Roasted fish from Makobar, Port Harcourt.

RF2=Roasted fish from Elekahia, Port Harcourt.

RF3=Roasted fish from Rivers State University, Port Harcourt.

RY1=Roasted yam from Makobar, Port Harcourt.

RY2=Roasted yam from Elekahia, Port Harcourt.

RY3=Roasted yam from Rivers State University, Port Harcourt.

SY1=Roasted suya from Makobar, Port Harcourt.

SY2=Roasted suya from Elekahia, Port Harcourt.

SY3=Roasted suya from Rivers State University, Port Harcourt.

MP1=Baked meat pie from Makobar, Port Harcourt.

MP2=Baked meat pie from Elekahia, Port Harcourt.

MP3=Baked meat pie from Rivers State University, Port Harcourt.

DN1 $=$ Fried dough nut from Makobar, Port Harcourt.

DN2=Fried dough nut from Elekahia, Port Harcourt.

DN3=Fried dough nut from Rivers State University, Port Harcourt.

\subsection{Proximate Composition}

Moisture, ash, crude fibre, Protein and fat contents were determined according to the method described by AOAC (2012). In the determination of the moisture content of the samples, five grams $(5 \mathrm{~g})$ of each test sample were weighed into the cans and its content was heated at $105^{\circ} \mathrm{C}$ for 4 hours. The cans at the end of heating were cooled in the desiccator and weighed. The Ash content was determined using the method of AOAC (2012). Two grams (2g) sample was weighed into previously ignited and cooled porcelain crucible. The crucible and sample was heated on a heating mantle (Gehardt, Germany) until no smoke. The crucible and content was transferred into a muffle furnace and was ashed for three

( 3 hours) at $550^{\circ} \mathrm{C}$. The crucible and ash was cooled in a desiccator and weighed. The crude fat was determined using a micro-extraction fat unit. Half $(0.5 \mathrm{~g})$ of the sample was weighed into a thimble, and placed inside the extraction flask. The flask and its content was placed on a multifunction shaker and oscillated for 3 hours. At the end of the extraction process, the thimble was removed and the flask was dried in an air oven (DHG- 9140A, China) for 30 minutes at $105^{\circ} \mathrm{C}$, cooled and weighed. Determination of the crude protein content followed the method by AOAC (2012) using the Kjeldahl method with the total \%Nitrogen $\times 6.25$ as factor. Half $(0.5 \mathrm{~g})$ of sample was weighed into digestion flask and then placed on a Kjedahl distillation unit and the distillate titrated. In the determination of Crude fibre, Half $(0.5 \mathrm{~g})$ of the sample was weighed and 
placed in a beaker. The content of the beaker was heated gently on a hot plate (Gehardt, Germany) for 10 minutes. The filter paper with insoluble material was dried at $105^{\circ} \mathrm{C}$ to a constant weight for one (1) hour. The dried filter paper and its content was incinerated to an ash at $500^{\circ} \mathrm{C}$ for 1 hour and cooled. Crude fat by Micro-extraction Procedure. Carbohydrate content was determined (by difference) i.e. 100 $-(\%+\%$ Ash $+\%$ Fat $+\%$ crude protein $+\%$ fibre $)$. The proximate compositions were carried out in duplicate samples and calculated in percentages.

\subsection{Data Analysis}

The mean values were subjected to statistical calculations which were performed using IBM SPSS (Statistical Package for Social Sciences) version 21.

\section{Results and Discussion}

Table 2. Proximate Composition of Street Vended Foods during the Raining Season.

\begin{tabular}{|c|c|c|c|c|c|c|}
\hline Samples & Moisture\% & Ash\% & Fat $\%$ & Protein \% & Crude Fibre\% & Carbohydrate\% \\
\hline RP1 & $51.58^{\text {ef }}+0.389$ & $1.32^{\mathrm{cd}}+0.240$ & $0.83^{\mathrm{g}}+0.099$ & $1.54^{\mathrm{g}}+0.000$ & $1.43^{\mathrm{gh}}+0.0 .99$ & $43.31^{b c}+0.431$ \\
\hline RP2 & $58.90^{\mathrm{cd}}+0.000$ & $1.27^{\mathrm{Cd}}+0.028$ & $1.16^{\mathrm{g}}+0.000$ & $1.03^{\mathrm{g}}+0.000$ & $2.73^{\mathrm{def}}+0.000$ & $37.65^{\mathrm{d}}+0.120$ \\
\hline RP3 & $58.90^{\mathrm{c}}+0.707$ & $1.21^{\mathrm{def}}+0.092$ & $1.02^{\mathrm{g}}+0.078$ & $1.03^{\mathrm{g}}+0.000$ & $2.70^{\mathrm{def}}+0.000$ & $38.40^{\mathrm{cd}}+0.431$ \\
\hline RF1 & $62.53^{\mathrm{a}}+0.099$ & $1.94^{\mathrm{bc}}+0.071$ & $4.12^{\mathrm{f}}+0.000$ & $29.83^{c}+0.000$ & $1.54^{\mathrm{fgh}}+0.000$ & $0.04^{\mathrm{f}}+0.021$ \\
\hline RF2 & $58.90^{b}+0.000$ & $2.29^{b}+0.000$ & $5.74^{\mathrm{def}}+0.078$ & $29.54^{\mathrm{c}}+0.247$ & $3.35^{\mathrm{cde}}+0.000$ & $0.19^{\mathrm{f}}+0.177$ \\
\hline RF3 & $58.90^{b}+0.707$ & $3.32^{\mathrm{a}}+0.198$ & $5.55^{\mathrm{ef}}+0.184$ & $30.51^{c}+0.057$ & $2.27^{\text {defgh }}+0.332$ & $0.00^{\mathrm{f}}+0.000$ \\
\hline RY1 & $52.30^{\mathrm{e}}+0.141$ & $2.23^{b}+0.085$ & $0.68^{\mathrm{g}}+0.021$ & $1.54^{\mathrm{g}}+0.000$ & $4.01^{\mathrm{bc}}+0.757$ & $39.25^{\mathrm{cd}}+0.552$ \\
\hline RY3 & $52.62^{\mathrm{d}}+0.601$ & $1.26^{\mathrm{cd}}+0.042$ & $1.26^{\mathrm{g}}+0.106$ & $1.63^{\mathrm{g}}+0.414$ & $1.94^{\mathrm{fgh}}+0.000$ & $41.30^{\mathrm{cd}}+0.594$ \\
\hline SY1 & $36.60^{\mathrm{j}}+1.556$ & $1.35^{\mathrm{cd}}+0.71$ & $7.95^{c}+0.212$ & $42.35^{b}+0.212$ & $6.45^{\mathrm{a}}+0.354$ & $5.55^{\mathrm{e}}+2.192$ \\
\hline SY2 & $38.15^{\mathrm{j}}+0.495$ & $0.90^{\mathrm{g}}+0.000$ & $7.00^{\text {cde }}+0.141$ & $47.35^{\mathrm{a}}+0.212$ & $3.40^{\mathrm{cd}}+0.424$ & $3.20^{\mathrm{ef}}+0.283$ \\
\hline SY3 & $45.35^{\mathrm{hi}}+0.061$ & $1.05^{\mathrm{def}}+0.071$ & $6.90^{\mathrm{g}}+0.141$ & $40.80^{b}+0.707$ & $4.70^{b}+0.000$ & $1.20^{\mathrm{ef}}+0.283$ \\
\hline MP1 & $46.79^{\mathrm{gh}}+0.636$ & $3.10^{\mathrm{a}}+0.177$ & $7.39^{\mathrm{cde}}+0.700$ & $4.70^{b}+0.242$ & $1.93^{\mathrm{fgh}}+0.000$ & $37.44^{\mathrm{d}}+1.520$ \\
\hline MP2 & $42.44^{\mathrm{i}}+0.163$ & $1.47^{\mathrm{cd}}+0.297$ & $12.71^{\mathrm{ab}}+0.898$ & $5.17^{\mathrm{ef}}+0.219$ & $2.14^{\mathrm{efgh}}+0.000$ & $37.44^{\mathrm{d}}+1.520$ \\
\hline MP3 & $35.96^{\mathrm{j}}+1.209$ & $0.65^{\mathrm{f}}+0.042$ & $14.43^{\mathrm{a}}+1.181$ & $6.13^{\mathrm{e}}+0.000$ & $3.34^{\mathrm{cde}}+0.000$ & $39.50 c^{d}+2.432$ \\
\hline DN3 & $31.98^{k}+1.400$ & $1.40^{\mathrm{cd}}+0.375$ & $7.62^{\mathrm{cd}}+0.170$ & $9.19^{\mathrm{d}}+0.495$ & $2.63^{\text {defg }_{+}}+0.007$ & $47.19^{\mathrm{ab}}+0.707$ \\
\hline
\end{tabular}

Values are means \pm standard deviation of duplicate samples.

Mean values bearing different superscripts in the same column differ significantly $(p<0.05)$.

Key:

RP1=roasted plantain from Makobar, Port Harcourt, RP2=roasted plantain from Elekahia, Port Harcourt.

RP3=roasted plantain from Rivers State University, Port Harcourt, RF1=roasted fish from Makobar, Lagos.

RF2=roasted fish from Elekahia, Port Harcourt, RF3=roasted fish from Rivers State University, Port Harcourt.

RY1=roasted yam from Makobar Port Harcourt, RY2=roasted yam from Elekahia, Port Harcourt.

RY3=roasted yam from Rivers State University, Port Harcourt.

SY1=suya from Makobar, Port Harcourt SY2=suya from Elekahia, Port Harcourt.

SY3=suya from Rivers State University, Port Harcourt.

MP1=meat pie from Makobar, Port Harcourt, MP2=meat pie from Elekahia, Port Harcourt.

MP3=meat pie from Rivers State University, Port Harcourt.

DN1=dough nut from Makobar Port Harcourt, DN2=dough nut from Elekahia, Port Harcourt.

DN3=dough nut from Rivers State University, Port Harcourt.

Table 3. Proximate Composition of Vended Street Foods during the Dry Season.

\begin{tabular}{|c|c|c|c|c|c|c|}
\hline Samples & Moisture\% & Ash\% & Fat $\%$ & Protein \% & Crude Fibre\% & Carbohydrate\% \\
\hline RP1 & $47.38^{\mathrm{efg}}+0.064$ & $0.99^{\mathrm{ef}}+0.000$ & $0.59^{\mathrm{g}}+0.000$ & $3.15^{\mathrm{h}}+0.000$ & $1.30^{\text {ede }}+0.000$ & $46.60^{b}+0.64$ \\
\hline RP2 & $51.74^{\mathrm{cd}}+0.212$ & $1.09^{\mathrm{def}}+0.134$ & $0.63^{\mathrm{g}}+0.049$ & $1.38^{\mathrm{i}}+0.000$ & $3.55^{b c}+0.283$ & $41.77^{c}+0.467$ \\
\hline RP3 & $47.65^{\mathrm{efg}}+0.000$ & $1.33^{\mathrm{cdef}}+0.085$ & $1.57^{\mathrm{g}}+0.566$ & $1.60^{\mathrm{i}}+0.311$ & $1.08^{\mathrm{de}}+0.141$ & $46.77^{b}+0.651$ \\
\hline RF1 & $59.12^{a}+0.481$ & $2.27^{b}+0.032$ & $4.53^{\mathrm{f}}+0.099$ & $27.34^{\mathrm{d}}+0.000$ & $2.26^{\text {bcde }}+0.035$ & $4.50^{\mathrm{fg}}+0.467$ \\
\hline RF2 & $59.56^{\mathrm{a}}+1.980$ & $1.61^{\mathrm{cd}}+0.078$ & $5.99^{\mathrm{f}}+0.708$ & $29.58^{c}+0.247$ & $2.40^{\text {bcde }}+0.000$ & $0.87^{\mathrm{g}}+1.103$ \\
\hline RF3 & $52.55^{\mathrm{bc}}+0.191$ & $1.93^{b c}+0.248$ & $14.25^{\mathrm{c}}+0.035$ & $26.40^{\mathrm{e}}+0.000$ & $2.76^{\mathrm{bcd}}+0.000$ & $2.12^{\mathrm{fg}}+0.113$ \\
\hline RY1 & $46.12^{\mathrm{fgh}}+0.064$ & $1.64^{\mathrm{cd}}+0.064$ & $0.76^{\mathrm{g}}+0.283$ & $1.40^{\mathrm{i}}+0.000$ & $2.28^{\mathrm{cde}}+0.000$ & $48.81^{\mathrm{d}}+0.283$ \\
\hline RY2 & $45.91^{\mathrm{fgh}}+1.831$ & $0.84^{\mathrm{f}}+0.078$ & $1.61^{\mathrm{g}}+0.042$ & $0.96^{\mathrm{i}}+0.000$ & $1.78^{\mathrm{cde}}+0.276$ & $48.92^{b}+2.072$ \\
\hline RY3 & $56.15^{\mathrm{ab}}+0.573$ & $1.48^{\mathrm{cde}}+0.269$ & $0.99^{\mathrm{g}}+0.007$ & $3.14^{\mathrm{h}}+0.000$ & $4.27^{\mathrm{ab}}+1.011$ & $33.99^{\mathrm{e}}+1.322$ \\
\hline SY1 & $38.58^{\mathrm{i}}+0.000$ & $2.48^{\mathrm{b}}+0.014$ & $22.22^{\mathrm{a}}+0.000$ & $26.89^{\mathrm{de}}+0.000$ & $4.33^{\mathrm{ab}}+0.000$ & $5.50^{\mathrm{f}}+0.014$ \\
\hline SY2 & $50.12^{\mathrm{cde}}+1.605$ & $3.32^{\mathrm{a}}+0.028$ & $6.37^{\mathrm{ef}}+0.311$ & $30.69^{b}+0.000$ & $6.25^{\mathrm{a}}+1.294$ & $3.26^{\mathrm{fg}}+0.651$ \\
\hline SY3 & $48.01^{\mathrm{def}}+0.764$ & $3.32^{\mathrm{a}}+0.014$ & $8.13^{\mathrm{de}}+0.792$ & $32.47^{\mathrm{a}}+0.318$ & $4.26^{\mathrm{ab}}+0.679$ & $3.82^{\mathrm{fg}}+0.983$ \\
\hline MP1 & $45.37^{\mathrm{fgh}}+1.570$ & $1.33^{\mathrm{cdef}}+0.106$ & $9.45^{d}+0.247$ & $6.92^{\mathrm{g}}+0.000$ & $2.75^{\text {bcd }}+0.488$ & $34.20^{\mathrm{e}}+0.728$ \\
\hline MP2 & $43.88^{\mathrm{gh}}+0.721$ & $1.38^{\mathrm{cdef}}+0.014$ & $9.06^{\mathrm{d}}+0.269$ & $6.59^{\mathrm{g}}+0.000$ & $2.95^{\mathrm{bcd}}+0.047$ & $35.89^{\mathrm{de}}+1.697$ \\
\hline MP3 & $42.36^{\mathrm{hi}}+0.834$ & $1.62^{\text {cd }}+0.311$ & $8.72^{d}+0.233$ & $6.58^{\mathrm{g}}+0.361$ & $1.84^{\mathrm{cd}}+0.707$ & $39.39^{\mathrm{cd}}+1.273$ \\
\hline
\end{tabular}




\begin{tabular}{lllllll}
\hline Samples & Moisture\% & Ash\% & Fat\% & Protein\% & Crude Fibre\% & Carbohydrate\% \\
\hline DN1 & $19.08^{\mathrm{k}}+0.990$ & $1.33^{\text {cdef }}+0.226$ & $8.38^{\mathrm{de}}+0.290$ & $8.40^{\mathrm{f}}+0.000$ & $1.30^{\text {cde }}+0.488$ & $61.52^{\mathrm{a}}+0.955$ \\
DN2 & $20.46^{\mathrm{jk}}+0.530$ & $0.94^{\mathrm{ef}}+0.071$ & $12.50^{\mathrm{c}}+1.549$ & $6.17^{\mathrm{g}}+0.580$ & $0.34^{\mathrm{e}}+0.000$ & $59.60^{\mathrm{a}}+0.509$ \\
DN3 & $23.52^{\mathrm{j}}+0.460$ & $0.89^{\mathrm{ef}}+0.276$ & $17.51^{\mathrm{b}}+0.403$ & $6.61^{\mathrm{g}}+0.000$ & $1.48^{\mathrm{cde}}+0.721$ & $50.01^{\mathrm{b}}+0.417$ \\
\hline
\end{tabular}

Values are means \pm standard deviation of duplicate samples.

Mean values bearing different superscripts in the same column differ significantly $(\mathrm{p}<0.05)$.

Key:

RP1=roasted plantain from Makobar, Port Harcourt, RP2=roasted plantain from Elekahia, Port Harcourt.

RP3=roasted plantain from Rivers State University, Port Harcourt, RF1=roasted fish from Makobar, Lagos.

RF2=roasted fish from Elekahia, Port Harcourt, RF3=roasted fish from Rivers State University, Port Harcourt.

RY1=roasted yam from Makobar Port Harcourt, RY2=roasted yam from Elekahia, Port Harcourt.

RY3=roasted yam from Rivers State University, Port Harcourt.

SY1=suya from Makobar, Port Harcourt SY2=suya from Elekahia, Port Harcourt.

$\mathrm{SY} 3=$ suya from Rivers State University, Port Harcourt.

MP1=meat pie from Makobar, Port Harcourt, MP2=meat pie from Elekahia, Port Harcourt.

MP3=meat pie from Rivers State University, Port Harcourt.

DN1=dough nut from Makobar Port Harcourt, DN2=dough nut from Elekahia, Port Harcourt.

DN3=dough nut from Rivers State University, Port Harcourt.

This study was designed to examine the effects of seasonal variations on the proximate compositions of vended street food in parts of Port Harcourt metropolis.

\subsection{Proximate Composition of Street Vended Foods During the Raining Season}

Result for proximate composition of street vended foods during the raining season is shown in Table 2. Moisture content ranged from $24.84 \%$ for doughnut from Makobar (DN1) to $62.53 \%$ shown in roasted fish also sourced from Makobar (RF1). Ash, fat, protein, crude fibre and carbohydrate content of the vended street foods ranged from $0.65-3.32 \%, 0.68-14.43 \%, 1.03-47.35 \%, 1.25-6.45 \%$ and $0.04-51.25 \%$, respectively. Protein content of MP 1-2 and DN2-3 (6.70\% and 5.12\%) and (9.17\% and 9.69\%). Suya samples from Makobar (SY1) gave high crude fibre of $6.45 \%$, high carbohydrate of $51.25 \%, 49.55 \%$ and $47.19 \%$ were shown in samples DN1, DN2 and DN3, respectively.

The moisture content of each of the food types were significantly different $(\mathrm{P}<0.05)$ with respect to location. This observation was evident in the moisture content of doughnut from Makoba (DN1) 24.84\%, suya from the Rivers State University, (SY3) $45.35 \%$ and $62.53 \%$ in roasted fish (RF1) from Makoba. Moisture content of (RF1) Makoba was significantly different $(\mathrm{P}<0.05)$ and higher than those from Elekahia (RF2) and the Rivers State University (RF3). The reason for this high moisture content in doughnut, suya and fish could be attributed to location and food handling processes. This agrees with the work of Egbebi and Seidu [10] that the moisture contents of suya samples from Akure and Ado-Ekiti ranged from 47.80 to $51.00 \%$ and 46.50 to $57.00 \%$ and observed significant differences in moisture contents which varied from one location to other.

The value of moisture content in suya ranged from $36.60-$ 45.35\% (Makoba and Rivers State University gate) during raining season appears to be lower than the values of moisture content obtained in suya from Akure and Ado -Ekiti, respectively [10]. However, this result may be due to the processing and handling methods which may leave the sample with high moisture content. The sample location
Makoba is at the coastal part of Port-Harcourt which is directly opposite Isaka channel with attendant high wind movement from the sea to the land during the day, while at the two other locations, urbanization may increase the level of humidity and making the air dryer and holding more water than at Makoba during the same raining season with low humidity. Especially, during the winter, humidity levels drop because cold air holds less moisture than warm air. Moisture, Ash and Fat contents of roasted plantain (RP1-3) ranged from Moisture (51.58 - 58.90\%), Ash (1.21 -1.30\%) and Fat (0.83-1.16\%) respectively during the raining season. High lipid content with high moisture as seen in the Suya, fish and Meat pie in this study increases the chances for rancidity and thus decreases the shelf life of the food [11].

According to Opeolu et al., [12], roasted plantain collected and analysed for proximate composition from Victoria Island of Lagos showed that, Moisture (8.0-8.1\%), Ash (2.2 - 2.3\%) and fat $(0.83-1.16 \%)$, respectively. The moisture values from the current study was significantly different $(\mathrm{P}<0.05)$ from the work of Opeolu et al., [12]. Roasted yam (RY1-3) and Meat pie (MP1-3) from the three different stations were significantly different $(\mathrm{P}<0.05)$ with respect to Protein and fat contents of the food type respectively during wet season. Ash, fat, protein, crude fibre and carbohydrate content of the street vended foods ranged from Ash (MP 0.65\% - RF $3.32 \%$ ), (RY $0.68 \%$ - MP14.43\%), Protein (RP 1.03 SY47.35\%), Crude Fibre (DN1.27\%-SY6.45\%) and Carbohydrate (RF $0.04 \%$ - DN51.25\%), respectively with regards to the various food types. Carbohydrate are the single most important source of food energy in the world. They comprise some of 40-80 percent of total food energy intake. Depending on local, cultural considerations or economic status [13]. Carbohydrate content of Doughnut ranged from $47.19 \%-51.25 \%$, indication that the vended food is a major source of carbohydrate. This may be attributed to the recipes, with flour as the main component. Ash content of roasted fish from the Rivers State University during the raining season (RF3) was significantly $(\mathrm{P}<0.05)$ higher than those from other locations. However, the lower ash content in the roasted plantain, yam and doughnut samples when compared to other 
studies is indicative of low mineral content [14], and hence influences its quality.

The fat content of each food type from specific locations were not significantly different $(\mathrm{P}>0.05)$ except for meat pie and doughnut. Fats are a concentrated source of energy, highly useful in increasing density of diet. This is particularly important for young children who have limited gastric capacity. For this reason and on the basis of fats providing essential fatty acids and their influence on the absorption of liposoluble nutrients [15]. Protein content of MP 1-2 and DN2-3 (6.70\% and 5.12\%) and $(9.17 \%$ and $9.69 \%)$ were significantly different $(\mathrm{P}<0.05)$ at the various locations during the raining season. However, the protein content of suya at Elekahia (SY2) was significantly different $(\mathrm{P}<0.05)$ from all other food types during the raining season. Suya samples from Makobar (SY1) gave high crude fibre of $6.45 \%$ and Roasted yam $(4.11 \%)$ while significantly $(\mathrm{P}<0.05)$ high carbohydrate of $51.25 \%, 49.55 \%$ and $47.19 \%$ were showed in samples DN1, DN2 and DN3, respectively. The high crude fibre of Suya and roasted yam during the raining season may be of health importance. According to Pereira and Pins [16]. The fiber content is beneficial as fiber in food helps eliminate bile acids, lower body cholesterol and creates variation in fecal bulk and transit time. High fiber diet intake prevents diet related diseases like cardiovascular disease, cancer of the colon and diabetes. Diet with high fiber content have been used for weight control and fat reduction as it provides satiety and thereby reduces the amount of energy given food that would be consumed [17].

The work of Opeolu et al., [12], did not address seasonal variations, which was a critical determinants in this study.

\subsection{Proximate Composition of Street Vended Foods During the Dry Season}

Table 3 Shows the Proximate composition of SVF during the dry season. Moisture content of RP1-3 ranged (47.38-51.74\%), RF1-3 (52.55-59.56\%), RY1-3 (45.91-56.15\%), SY1-3 (38.58 - 50.12\%), MP1-3 (42.36-45.37\%), DN1-3 (19.08-23.52\%). Ash values RP1-3 ranged from (0.99-1.33\%), RF1-3 (1.61-2.27\%), RY1-3 (0.84-1.64\%), SY1-3 (2.48-3.32\%), MP1-3 (1.33 - 1.62\%), DN1-3 (0.89 - 1.33\%).

The Ash content is in agreement to the reports of Osundahunsi et al., [18], and Abioye at el., [19], for street vended foods. The fat content of roasted plantain (RP1-3) ranged from (0.59-1.57\%), RF1-3 (4.53-14.25\%), RY1-3 (0.76-1.61\%), SY1-3 (6.37-22.22\%), MP1-3 (8.72- 9.45\%, DN1-3 (8.38-17.5\%). For protein content, RP1-3 ranged from (1.38-3.15\%), RF1-3 (26.40- $29.58 \%$,), RY1-3 (0.96-3.14\%), SY1-3 (26.89- 32.47\%), MP1-3 (6.58$6.92 \%)$, DN1-3 (6.17- 8.40\%). High crude fibre of $6.25 \%$ was shown in suya from Elekahia (SY2). High protein of $8.40 \%$ was shown in DNI from Makoba. Proximate composition of vended street food during the dry season showed significant values respectively, fat (RP1 0.59\% SY1 22.22\%), protein (RY2 0.96\% - SY3 32.47\%), crude fibre (DN2 0.34\% - SY2 6.25\%), ash (RY2 0.84\% - SY3
$3.32 \%$ ) and carbohydrate content ranged (RF2 $0.87 \%$ DN1 $61.52 \%$ ). The findings in this work is in collaboration with the report of Jido et al, [20], The results showed the proximate compositions of selected street vended fried foods (yam, sweet potato, akara and rice masa), in which percentage moisture, ash, fat, protein and carbohydrate were high. The moisture content of each of the food types in this study were significantly different $(\mathrm{P}<0.05)$ with respect to location SY1 and SY2 (38.58-50.12\%), Roasted Fish from Elekahia recorded the highest moisture level, RF2 (59.56\%), while Doughnut from Makoba recorded the least moisture content DN1 (19.08\%). This is true of DNI due to the nature of the food product which tends to have high carbohydrate content as showed in the study with $61.52 \%$ at the same station. Moisture content of suya from Makoba and Elekahia ranged from (38.58-50.12\%) appears to agree with the work of Egbedi and Seidi [10]. The moisture content of a food sample shows the shelf life stability of the product. The moisture contents of the food samples were high. Moisture content in excess of $14 \%$ in foods has danger of bacteria action and mould growth to produce undesirable changes [1].

Dry season are characterize with high humidity with less water in the air. This has a corresponding impact on food products as the water activity is driving by the humidity of the surrounding environment.

Higher moisture content of the roasted fish when compared to the other food samples shows that the fish has low storage capacity and is easily perishable, though the high moisture content will enhance food digestion and peristaltic movement on consumption [21]. For Ash, roasted yam at Elekahia recorded the least content with $0.84 \%$ with a corresponding low protein value of $0.96 \%$, while suya at the Rivers State University recorded the highest ash content of $3.32 \%$ and a corresponding high protein value of $32.47 \%$ at the same location during the dry season. The least Fat content was recorded by roasted plantain at Makoba, while suya at the same location recorded the highest Fat content of $22.22 \%$. There was no significant different $(\mathrm{P}>0.05)$ in the fat content of roasted plantain (RP1-3), roasted yam (RY1-3) and meat pie (MP1-3), with respect to location and specific food type at dry season. High crude fibre of $6.25 \%$ was recorded in suya from Elekahia (SY2), this was however, statistically different $(\mathrm{P}<0.05)$ from $4.33 \%$ and $4.26 \%$ showed in samples SY1 and SY3, respectively. According to FAO [22], increased fibre consumption may contribute to an incidence of certain diseases, including diabetes, coronary heart disease, colon cancer and various digestive disorders; it also absorbs water thus producing soft and bulky stools. Hence the consumption of unbalanced, fat-rich snacks low in fibres such as fish roll and doughnut, yam can lead to constipation and heart bum, also frequently eating of such snacks promotes obesity [23].

Fish and Suya recorded the highest protein value (which ranged from $26.40-29.58 \%$ and $26.89-30.69 \%$, which was significantly different from the high protein of $8.40 \%$ showed in DNI from Makoba, this was however statistically different 
$(\mathrm{P}<0.05)$ from $6.17 \%$ and $6.61 \%$ recorded in samples DN2 and DN3 respectively during dry season. Fish and Suya are major source of protein requirements, while the high level of protein in doughnut may be attributed to source of oil and processing method and ingredients. In a similar study by Pikuda and Ilelaboye [24], the protein content of puff-puff varied significantly from $5.69 \mathrm{~g} / 100 \mathrm{~g}-8.55 \mathrm{~g} / 100 \mathrm{~g}$, these differences could be attributed to the source of the oil and composition of the recipe used by the vendors to prepare the puff- puff. Akusu and kiin- Kabari [25], reported that the crude protein content of moi-moi is as high as $21.89 \%$ and $20.50 \%$ and Ejima and Ejima [26] the protein quality of a diet is usually a measure of the ability to promote growth. According to Francis and Mogens [5] that many individuals and families and communities in different parts of the world-and especially in low-income, developing countries-do not receive sufficient protein intake to meet their physiological needs. Protein malnutrition effects in particular vulnerable groups such as children, pregnant and nursing mothers and the child at breast after weaning, and during subsequent early stages of growth and development. The high protein content of fish, suya, and meat pie as street vended foods, which are affordable due to their various savings mode and quantities is able to close the gap of effects of protein deficiencies.

For Meat Pie across the locations (MP1-3) Protein content were not significantly different $(\mathrm{P}>0.05)$. DN2 recorded the least crude fibre of $0.34 \%$, while the highest crude fibre was recorded by SY2 at the same location during dry season. The carbohydrate content of each of the food types were significantly different $(\mathrm{P}<0.05)$ with respect to location except suya, with values of $5.50 \%, 3.26 \%$ and $3.82 \%$ which were not statistically different $(\mathrm{P}>0.05)$ in spite of location. According to Abiodun et al. [27] results obtained from Doughnut revealed that the protein content of the flour increased with increase in Bambara nut addition from 10.88$11.78 \%$. Significant differences $(\mathrm{p}<0.05)$ were observed in the fat, ash, and crude fiber $(1.88-2.23 \%, 1.22-1.88 \%$, and $3.96-4.02 \%$ ) respectively.

\subsection{Effect of Seasonal Variations and Location on the Nutrient Content of Selected Street Vended Foods}

The Analysis of Variance from three-way factorial analysis showed that the interaction effect of season and location on the proximate composition of selected street vended foods were significant $(\mathrm{P}<0.05)$. From the study roasted fish recorded the highest moisture content of $62 \%$ at station 1 (Makoba) during the raining season and 59\% during the dry season which showed a significant difference $(\mathrm{P}<0.05)$ during the two seasons. The location of Makoba is coastal part of Port Harcourt closer to the Makoba Jetty for shipping and other industrial activities and surrounded with the mangrove swamp of the Delta. This was closely followed by roasted plantain (RP) that recorded high moisture content of $54 \%$ at station 1 (Makobar) during the dry season and low moisture of $45 \%$ at station 3 (Rivers State University) during the dry season. Whereas, meat pie showed relatively higher moisture value of $34 \%$ at station 3 (Elekahia), than $30 \%$ recorded at station 3 higher during the dry season. This is in agreement with the work of Watts [28] and Sunful et al [29].

Doughnut at Makoba recorded the least moisture content of $19 \%$ during the dry season when compared to the same product during raining season with $25 \%$. However, the value of moisture content of $25 \%$ was recorded at station 3 (Rivers State University) during the dry season, while the value was $31 \%$ during the raining season. Product with high water activity are prone to high microbial load compared to product with low water activity. One can infer that Doughnut with least water activity are likely to have more shelf life than those with higher water activity during raining season [1].

The ash content of meat pie sourced from station 3 (RSU) was $0.65 \%$, this was significantly $(\mathrm{P}<0.05)$ lower than meat pie sourced from station 1 during the raining season. While roasted fish from station 3 gave high ash content of 3.35\%, which was lower than $2.265 \%$ noted in roasted fish from station 1 during the raining season. Similarly, the ash content of suya at station 2 and 3 recorded high values of $3.32 \%$ respectively and this was not significantly different $(\mathrm{P}>0.05)$, but was significantly different from station1 $(\mathrm{P}<0.05)$. The ash content of a feedstuff is the inorganic residue remaining after the organic matter has been destroyed by combustion in the muffle furnace $[9,30]$.

In considering the effect of seasonal variations and locations, Meat pie from station3 gave the higher fat value of $14.43 \%$ during the raining season, and the fat value was low during the dry season at the same station, $(8.72 \%)$, while suya sourced from station 1 gave the highest fat value of $22.22 \%$ during the dry season, but was low in fat during the raining season at the same station. During the dry season, roasted fish (RF) was high in fat, but low during the raining season at the same station. Roasted plantain and roasted yam recorded the least fat values at all stations and seasons. Suya from station 2 (Elekahia) recorded the highest value of protein $(47.35 \%)$ during the raining season, while high value of protein $(32.47 \%)$ was recorded during the dry season in suya sourced from station 3 (RSU). The protein content of roasted plantain and roasted yam were low $(1.03 \% \mathrm{RP}$ and $1.38 \% \mathrm{RY}$ ) at all stations during raining and dry season respectively, and thus, showed no significant difference $(\mathrm{P}>0.05)$. The reason for the low value of protein in plantain and yam, could be attribute to the fact that Plantain and yam were traditional foods not known for high protein value, except enriched in the course of food formulations.

Suya recorded highest crude fibre value $(6.45 \% \mathrm{SY} 1)$ from station 1 during the raining season, while a higher crude fibre value $(6.25 \%$ SY2) during the dry season was noted in suya from station 2. The effect of season and locations on crude fibre content of Suya was not significant $(\mathrm{P}>0.05)$ The study also showed that doughnut recorded the least value $(0.34 \%$ DN2) during dry season at station 2 Elekahia, while during the raining season for the same food product doughnut recorded low crude fibre value $(1.27 \% \mathrm{DN} 1)$ for station1 at Makoba The study showed a significant difference $(\mathrm{P}<0.05)$ of roasted yam with a higher crude fibre values $(4.11 \%$ RY2) during the 
raining season compared to roasted yam during the dry season with a low value $(1.78 \%$ RY2) at the same station.

Lowest carbohydrate value of $(0.04 \%$ RF 1$)$ was observed in roasted fish from station 1, during the raining season, and a corresponding value of $(2.12 \%$ RF3) was recorded for roasted fish at station 3 during the dry season. It was observed that the lowest carbohydrate value $(0.87 \%$ RF2) was recorded during the dry season by roasted fish from station 2, while the value for raining season for the same product at the same station was $(0.19 \%$ RF2). In general, it was commonly observed that carbohydrate value was generally low during the raining season when compared to high carbohydrate content for food products at the dry season. This also showed the effect of season on the proximate composition of food product.

\section{Conclusion}

The study showed that the moisture content, Protein, Ash, Carbohydrate, Crude fibre of each of the food types were significantly different $(\mathrm{P}<0.05)$ with respect to location during dry and raining seasons respectively. However, there was no significant different $(\mathrm{P}>0.05)$ in the fat content of roasted plantain (RP1-3), roasted yam (RY1-3) and meat pie (MP1-3), with respect to location and specific food type during the dry season. Three-way factorial analysis showed that the interaction effect of seasonal variation and location on the proximate composition of selected street vended foods were significantly different $(\mathrm{P}<0.05)$ and may be due to the processing and food handling methods, species, seasonal effects on the raw materials and not particularly about the location of food samples. This conclusion is in agreement with the findings of Pikuda and Ilelaboye, [24], in a similar study, It was also observed that the location of purchase did not have any pronounced effect on the nutrient of street vended snacks rather it was the processing methods and the species of the raw materials used in the preparation of the snacks that affect their proximate compositions.

\section{References}

[1] Ihekoronye AI, Ngoddy PO (1985) Integrated food science and technology for the tropics, McMillian Publishers, Ltd, London pp: 4-5, 293-298.

[2] Martins, J. H. (2006). Socio - economic and Hygiene Features of Street Food Vending in Gauteng. South African Journal of Clinical Nutrition, 19 (1): 18-25.

[3] Mosupye, F. M., \& Holy, A. (1999). Microbiological quality and safety of ready to eat street vended foods in Johannesburg, South Africa. Journal of Food Prot. [PubMed]. 62: 1278-1284.

[4] FAO and WHO (2005) Informal food and distribution sector in Africa (Street Foods): Importance and challenges. Regional Conference on Food Safety for Africa.

[5] Francis A and Mogens J (1975). Protein and Nutrition Policy in Low- income Countries. The General Publishing Company Limited, Toronto. 1-2.
[6] Dosumu OO, Oluwaniyi OO, Awolola GV \& Oyedeji OO (2012). Nutritional Composition and Antimicrobial Properties of three Nigerian Condiments. Nigerian Food Journal 30: 43-52.

[7] Oyet, G. I, Kiin-Kabari, D. B, Akusu, M. O \& Achinewhu, S. C (2020). Impact of Wet and Dry Seasons on the Distribution of Polycyclic Aromatic Hydrocarbons in Selected Vended Street Foods in Parts of Port Harcourt Metropolis. European Journal of Nutrition \& Food Safety 12 (1): 16-29, 2020; Article no. EJNFS. 54483 ISSN: 2347-5641.

[8] Brian A. F and Allan G C (1985). Food Science, a chemical approach. 4th edition. Printed in Great Britain for Hodder and Stoughton Educational.

[9] AOAC (2012). Association of official Analytical Chemists, Official Methods of Analysis. 19th edition, Washington, D. C, U.S.A.

[10] Egbebi, A. O \& Seidu K. T (2011). Microbiological evaluation of Suya (dried smoked meat) sold in Ado and Akure, South West Nigeria. European Journal of Experimental Biology. 1 (4): $1-5$.

[11] Ashiedu JJ (1998) Processing and tropical crops. Macmillian Publishers Ltd London and Basingstoke.

[12] Opeolu, B. O., Adebayo, K., Okuneye, P. A., \& Badru, F. A. (2010). Physicochemical and Microbial Assessment of Roadside Food and Water Samples in Lagos and Environs. J. Appl. Sci. Environ. Management. 14 (1) 29-34.

[13] FAO. (1998). Carbohydrate in Human Nutrition. Food and Agriculture Organization of the United Nations, Rome, Italy, pp: 66.

[14] Oranusi S, Braide W, Eze UC, \& Chinakwe E (2013) Quality aspects of African salad. Journal of Emerging Trends in Engineering and Applied Sciences 4: 287-292.

[15] Jose, M. B., T. Benjamin, B. R. Moises \& S. S. Nevin, (1989). Nutritional goals for health in Latin America. UNU Food and Nutrition Bulletin, pp: 85.

[16] Perreira MA, and Pins JJ (2000) Dietary fiber and cardiovascular disease: experimental and epidemiologic advances. Current Atherosclerosis Reports 2: 494-502.

[17] Ekop AS (2004) Effects of processing on the chemical composition of maize. Proceedings of abstract, 24th Annual Conference of Nigeria Society of Biochemistry and molecular Biology, University of Calabar, Nov. 24th-27th.

[18] Osundahunsi OF, Fagbemi TN, Kesselman E,\& Shimoni E (2003) Comparison of the physicochemical properties and pasting characteristics of flour and starch from red and white sweet potato cultivars. Journal of Agricultural Food Chemistry 51: 2232-2236.

[19] Abioye, VF, Ade-Omowaye BIO, Babarinde GO, \& Adesigbin MK (2011) Chemical, physico-chemical and sensory properties of soy-plantain flour. African journal of food science 5: 176-180.

[20] Jido, B. A., Haruna, M., Abdullah, M. A., Shehu, A. A., Sadisu, F. U., Yahaya, A. \& Ali, M. (2019). Determination of Proximate Composition of Selected Street Vended Fried Foods Sold in Wudil Town Kano State, Nigeria. Chemistry Research Journal, 2019, 4 (1): 33-39. 
[21] Ekong GS, Ogban PI, Ibia TO, \& Adam AA (2009) Evaluation of nutrient -supplying potentials of fluted pumpkin (Telfairia occidentalis, Hook, F) and Okra (Abelmoschus esculentus) (L) Moench. Academic Journal of Plant Sciences 2: 209-214.

[22] FAO. (1988). Roots, Tubers, Plantain and Bananas in Human Nutrition. Food and Agriculture Organization of the United Nations, Rome, Italy.

[23] SAN. (2003). Fast Food. The Swiss Association for Nutrition, Berne.

[24] Pikuda. O. O and Ilelaboye, N. O. A (2009). Proximate Composition of Street Snacks Purchased from Selected Motor Parks in Lagos. Pakistan Journal of Nutrition, 8: 1657-1660.

[25] Akusu OM, and Kiin-Kabari DB (2012) Protein quality and sensory evaluation of moi-moi prepared from cowpea/maize flour blends. African Journal of Food Science 6: 47-51.
[26] Ejima OAW and Ejima OS (2015) Nutritional potential of improve fresh maize moi-moi compared with bean moi-moi. Int J Innov Res Sci Eng. Techno 2: 559-572.

[27] Abiodun, O. A, Oladeinde, O. O., Adeyeye, S. A. O, \& OLADEJI, I. (2017). Quality Assessment of Doughnut Prepared from Wheat Flour Enriched with Bambara Nut Flour. Journal of Culinary Science \& Technology, 15 (3), 272-283.

[28] Watts BM (1989) Basic sensory methods for food evaluation. The International Development Research Centre, Ottawa, Canada. p. 159

[29] Sunful RE, Sadik A, Darko S (2010) Nutritional and sensory analysis of bean and wheat flour composite cake. Pakistan Journal of Nutrition 9: 794 -796.

[30] MAFF., 1981. The Analysis of Agriculture Materials. 2nd Edn, HMSO., London, pp: 22. 